\title{
DOMINANT FACTORS AFFECTING SEAWEED (Gracilaria verrucosa) PRODUCTION IN ACID SULFATE SOILS-AFFECTED PONDS OF LUWU REGENCY, INDONESIA
}

\author{
Akhmad Mustafa")\# and Jesmond Sammut ${ }^{* *}$ \\ ") Research Institute for Coastal Aquaculture \\ *) School of Biological, Earth and Environmental Sciences, \\ The University of New South Wales, Sydney, NSW 2052, Australia
}

(Received 22 October 2010; Accepted 3 December 2010)

\begin{abstract}
Most of brackish water ponds used for seaweed (Gracilaria verrucosa) culture in Luwu Regency, South Sulawesi, Indonesia are constructed on acid sulfate soil. Despite this inevitable condition, opportunities remain open to increase the seaweed production. The research was conducted to study the dominant factors that affect the seaweed production in ASS-affected ponds of Luwu Regency. As a dependent variable in this research is seaweed production. Independent variables were grouped into: (a) farmer status factor, consisting of 9 variables; (b) pond condition factor, consisting of 8 variables; (c) pond management factor, consisting of 29 variables; (d) soil quality factor, consisting of 17 variables and (e) water quality factor, consisting of 11 variables. Multiple regression with dummy variable was used to analyze the data in prediction dependent variable. Results show that the average of seaweed production in ASS-affected pond of Luwu Regency is 11,000 kg dry/ha/year. Seaweed production can be increased through: (a) decreasing dosage of urea and $\mathrm{KCl}$ and increasing dosage and frequency of fertilizer containing phosphate; (b) increasing water depth in the pond and decreasing percentage of water exchange, (c) conducting remediation to increase the soil $\mathrm{pH}$ and decreasing the concentration of Fe in the water, (d) increasing stocking density of milkfish to decrease the epiphyte population and (e) increasing the frequency of the farmer to attend trainings.
\end{abstract}

KEYWORDS: dominant factor, Gracilaria verrucosa, acid sulfate soil, brackish water pond, Luwu Regency

\section{INTRODUCTION}

The acid sulfate soils (ASS) are the common name given to soil or sediment that has pyrite (Sammut \& Lines-Kelly, 2000). In Indonesia, about 6.7 million hectares of land are considered as ASS (Klepper et al., 1990) and 35\% of them have been converted to brackish water ponds. There are approximately 9,000 ha of ASS-affected pond in Luwu Regency, South Sulawesi province (Mustafa \& Ratnawati, 2005). New ASS-affected and improper preparation of dyke ponds contain high toxic elements and low macro nutrient that can lower the growth and survival rate of shrimp and fish. Consequently, many ASS-affected ponds remain abandoned or have low productivity.

\# Corresponding author. Research Institute for Coastal Aquaculture, Jl. Makmur Dg. Sitakka, Maros 90512, South Sulawesi, Indonesia. Tel.: + 62411371544

E-mail address: akhmadmustafa@yahoo.com 
In Revitalization of Agriculture, Fisheries and Forestry Program that has been proclaimed by the President of Indonesian Republic on 11 Juny 2005 , seaweed is considered as one of several main fisheries commodity that is taken into priority to be revitalized besides shrimp and tuna. Seaweed has been an important fisheries commodity for developing countries because of its value as export commodity, easy to culture, small capital requirement, suitable for small-scale business, fast to alleviate the poverty problems and creating the opportunities for employment. Seaweed culture is a productive yet environmentally friendly alternative livelihood for coastal populations (Sukadi, 2006). Among seaweed species, Gracilaria sp. (Rhodophyta) is an important algae for commercial industries and has many applications such as agar extraction (Westermeier et al., 1993; Marinho-Soriano \& Bourret, 2003; FreilePelegrín \& Murano, 2005; Sukadi, 2006), natural product with important bioactivity (Santelices \& Doty, 1989), human food, feed material for more economically-important organisms such as sea urchins and abalone (Santelices \& Doty, 1989), food binder for fish feed (Peñaflorida \& Golez, 1996; Valente et al., 2006) and an efficient heavy metal container (Sfriso et al., 1994).

Daud et al. (1994) stated that the quality of Gracilaria verrucosa was strongly affected by the quality of the bottom of ponds. The productivity of ponds used in culturing $G$. verrucosa can be increased through improving the culture management and the irrigation facility (Retnowati et al., 1995). Ponds with low productivity or not suitable for shrimp can be used to culture G. verrucosa (Mubarak et al., 1990; Sukadi, 2006). G. verrucosa was also cultured in ASS-affected ponds (Mustafa \& Ratnawati, 2005). However, the information is still limited about the factors that affect the production of seaweed in ASS-affected ponds. G. verrucosa production level in ASS-affected pond with water depth of $0.50 \mathrm{~m}$ is higher than that of cultured in ponds with water depth of $0.25,0.75$, and $1.00 \mathrm{~m}$ reared for 45 days (Hendrajat \& Pantjara, 2004).

Luwu Regency is a centre of G. verrucosa development in South Sulawesi province (Anonymous, 2003a). The quantity and quality of $G$. verrucosa harvested in ASS-affected ponds of Luwu Regency is better than in any other places. The quality of $G$. verrucosa from Luwu Regency is considered the best in Indo- nesia (Anonymous, 2003b). Culture technique management employed by G. verrucosa farmer in ASS-affected ponds of Luwu Regency is different from one to another (Mustafa \& Ratnawati, 2005). The different management techniques in $G$. verrucosa culture will have different effects on the production (Rasjid et al., 1993). Extreme water temperature and salinity may adversely affect agar product quality of $G$. verrucosa (Daugherty \& Bird, 1988) and have positively correlated with Gracilariopsis bailinae growth and net production (Guanzon et al., 2004). Daily aeration periods have an effect on the Gracilaria sp. production, but it does not affect on agar content, gel strength, or gelling and melting temperatures (Guerin \& Bird, 1987). Efficient large-scale and long-term tank cultivation of Gracilaria sp. has been reported from Florida, USA (Capo et al., 1999). In Israel, the various aspects involved with commercial culture of Gracilaria conferta have been thoroughly developed since the 1980s (Friedlander et al., 1987). A variety of production ecology studies has been important in the development of various farming methods, and increased requirements for farmed Gracilaria $\mathrm{sp}$. in the near future are likely to stimulate new approaches (Santelices \& Doty, 1989). Because of that, the research was conducted to study the factors that affect the seaweed production in ASS-affected ponds of Luwu Regency, Indonesia.

\section{MATERIALS AND METHODS}

The research was conducted in Walenrang and Ponrang districts, Luwu Regency, South Sulawesi Province, Indonesia (Figure 1). Ponds in the coastal land of Walenrang and Ponrang district have been identified as ASS (Mustafa, 2006). The initial stage of the research was to see the whole pond used for culturing $G$. verrucosa. Ponds selected were based on their distribution and seaweed farmers selected were respondent of this research. The locations of ponds selected were determined with Global Positioning System (GPS).

Production, farmer status, and pond management factors were identified by using the pre-tested questionnaire. To know the pond condition factor, observation and measurement in the field were performed. Soil samples were taken in the each pond using soil auger in soil depth of $0-0.20 \mathrm{~m}$. Soil samples were collected from three places in each pond and combined as one sample from the pond. At the 


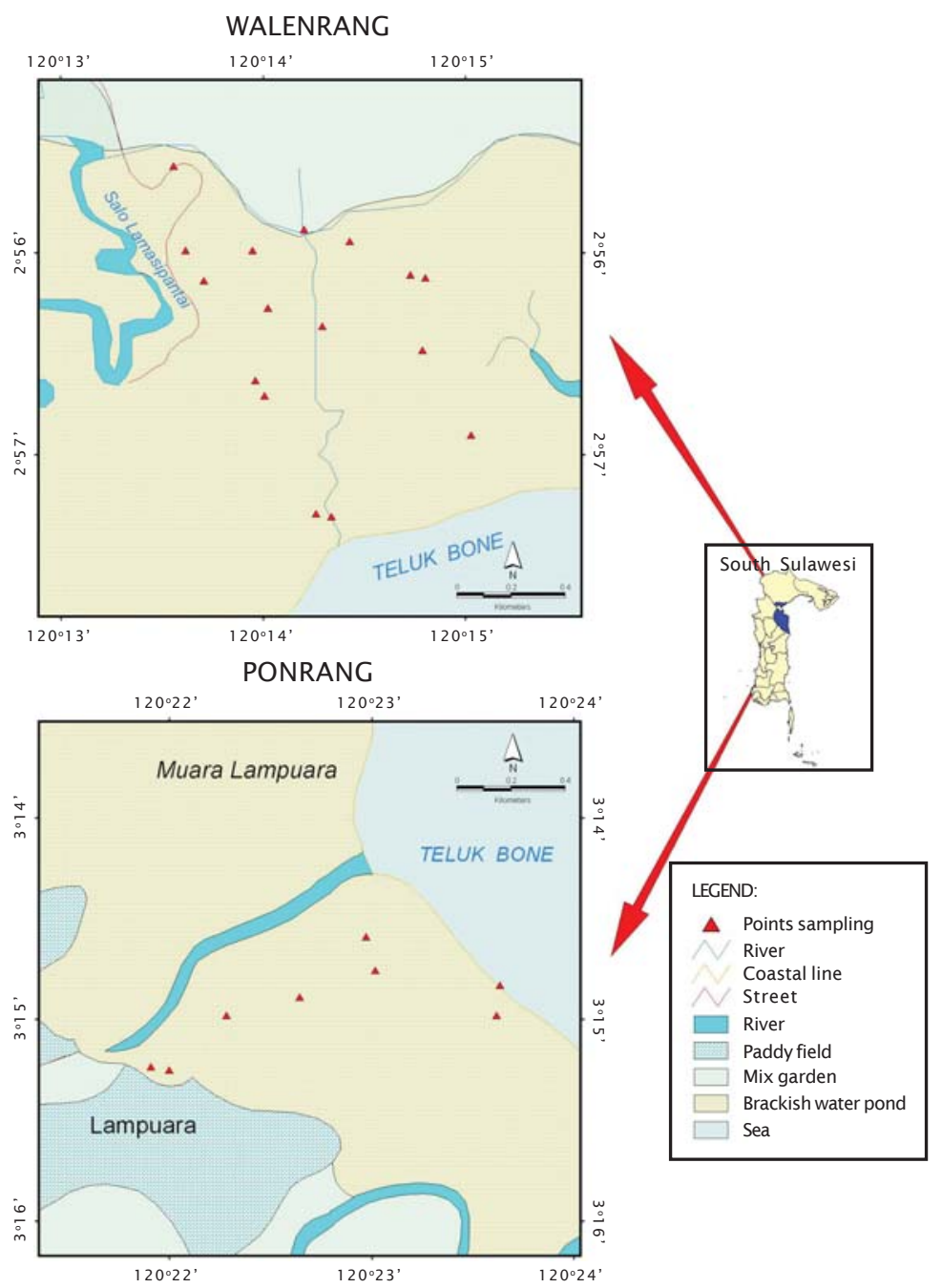

Figure 1. Sampling points of the research in Luwu regency, Indonesia (map courtesy of Hasnawi, RICA)

time of sampling, there were measurements of field $\mathrm{pH}\left(\mathrm{pH}_{\mathrm{F}}\right)$ (Ahern \& Rayment, 1998), field $\mathrm{pH}$ after oxidation with $30 \%$ hydrogen peroxide $\left(\mathrm{pH}_{\mathrm{FOX}}\right)$ (Ahern \& Rayment, 1998), and redox (reduction oxidation) potential with redox-meter and texture with feel method. After sample collection in the field, soil samples were immediately placed in a cold box containing ice to minimize bacterial activity. In the laboratory, soil samples were dried in oven at $80^{\circ} \mathrm{C}-85^{\circ} \mathrm{C}$ for at least 48 hours (Ahern \& Blunden, 1998). The chemical property of the soil was analyzed at the ACIAR Project Soil Laboratory owned by the Research Institute for Coastal Aquaculture
(RICA) in Maros Regency, South Sulawesi. After dried, soil was pulverized with a soil crusher to pass a 20-mesh screen, and stored in plastic bags. The measured variables were $\mathrm{pH}_{\mathrm{KCl}}\left(\mathrm{pH}\right.$ of filtered $1: 201 \mathrm{M} \mathrm{KCl}$ extract), $\mathrm{S}_{\mathrm{KCl}}$ (KCl extractable S), $S_{p}$ (peroxide sulfur after peroxide digestion), $S_{\mathrm{POS}}$ (peroxide oxidisable, $\mathrm{S}_{\mathrm{p}}-\mathrm{S}_{\mathrm{KC}}$ ), TAA (total actual acidity in $1 \mathrm{M} \mathrm{KCl}$ titrated to $\mathrm{pH}$ 5.5), TPA (total potential acidity in $1 \mathrm{M} \mathrm{KCl}$ peroxide digest titrated to $\mathrm{pH} 5.5$ ), TSA (total sulfidic acidity, TPA - TAA), pyrite (Ahern \& Rayment, 1998; Ahern et al., 1998b, 1998c), Al, Fe, and $\mathrm{PO}_{4}$ (Menon, 1973; Melville, 1993). 
Water quality measured in situ with Hydrolab ${ }^{\odot}$ Minisonde, including temperature, salinity, and $\mathrm{pH}$ in midday between 10:0014:00. Water samples for chemical analysis were taken with a column sampler. Each water sample was a composite of subsamples collected from three places in each pond. Water samples were preserved according to APHA (2005). Each water sample was measured in Water Laboratory of RICA for $\mathrm{PO}_{4}$ by ascorbic acid method (APHA, 2005), $\mathrm{NH}_{4}$ by phenat method (APHA, 2005), $\mathrm{NO}_{3}$ by cadmium reduction method (APHA, 2005), $\mathrm{NO}_{2}$ by colorimetric method (APHA, 2005), Fe by phenanthroline method (APHA, 2005), $\mathrm{SO}_{4}$ by turbidimetric method (APHA, 2005), total suspended solid by gravimetric method (APHA, 2005) and total organic matter by titrimetric $\mathrm{KMnO}_{4}$ method (APHA, 2005).

As a dependent variable in this research was $G$. verrucosa production. Independent variables were grouped into: (a) farmer status factor, consisting of 9 variables; (b) pond condition factor, consisting of 8 variables; (c) pond management factor, consisting of 29 variables; (d) soil quality factor, consisting of 17 variables and (e) water quality factor, consisting of 11 variables. The model of multiple regression equation will be tested as:

$$
\begin{array}{r}
Y=a+b_{1} X_{1}+b_{2} X_{2}+b_{3} X_{3}+\ldots+b_{i} X_{i} \\
\ldots \ldots \text { (Equation 1) }
\end{array}
$$

Descriptive statistics was used to extract general information of the data. Multiple regression with dummy variable was used to analyze the data in prediction dependent variable. The dummy variables in this research were: sex, level of education, land status, the other job excluding as a farmer, former use of the land, initial pest control, month of stocking, adaptation when stocking, time stocking, water source, water exchange system, continuing pest control, presence of pest and soil texture. Coefficient of correlation was determined to know the relationship between soil variables. A high correlation coefficient indicates a strong relationship between soil variables, soil variable that was easy to measure in the field was selected for the next analysis. To validate the data from interview, coefficient of correlation was also determined. Reliability Test was used to test the reliability of measure tools of data from interview. Durbin-Watson Test was used to detect whether indication of multi-co-linear- ity among independent variables. In choosing the best of multiple regression equation the forward elimination procedure was used (Draper \& Smith, 1992). $\mathrm{R}^{2}$ Test was used to know how much the dependent variables can explain the independent variable. $\mathrm{F}$ Test was used to test the significant of the regression model and t Test for testing the significance of the regression coefficient of the independent variables at significant level of 0.05 . All statistical analyses were performed with a computerized statistical package, Statistical Product and Service Solution (SPSS) version 16.0.

\section{RESULTS AND DISCUSSION}

Almost all respondents or the farmers seaweed in ASS-affected pond of Luwu Regency are male. Only one farmer was a female. The average age of the farmers was 45 years old. The minimum and maximum of farmer experience in working with brackish water pond operation were 1 and 36 years, respectively (Table 1). The seaweed farmers have low level educational attainment. Most of them had finished primary school and the farmers are rarely to attend trainings related to brackish water ponds. With their low educational attainment, they might be unaware of the improved brackish water ponds technology. Padda (1986) claimed that farmers in Jeneponto Regency, South Sulawesi have the average experience of 19 years working in brackish water ponds with level of education mostly primary school and their age was 53 years old. About $81.28 \%$ of brackish water pond farmers in Bulukumba, Takalar and Maros regencies, South Sulawesi only graduated from primary school (Hanafi, 1990). Majority of the farmer are working full time in their brackish water ponds. Aside from the brackish water farmers themselves, the other family members are also helping in some way in brackish water pond activity. In general, most of the farmers are landowners and only small numbers are contract worker.

Source of sea water for brackish water pond in Luwu Regency is Bone bay. Distance of ponds to the sea is from 0 to $2,000 \mathrm{~m}$ with $1,070 \mathrm{~m}$ in average. Pond water is collected from Pantai Lamasi and Labonro-bonro rivers in Walenrang district and Lampuara river in Ponrang district. Most of the brackish water ponds are built on nipa palm (Nypa fruticans) vegetated areas and small number on mangrove (especially Rhizophora apiculata and Rhizophora mucronata) and mixed nipa palm 


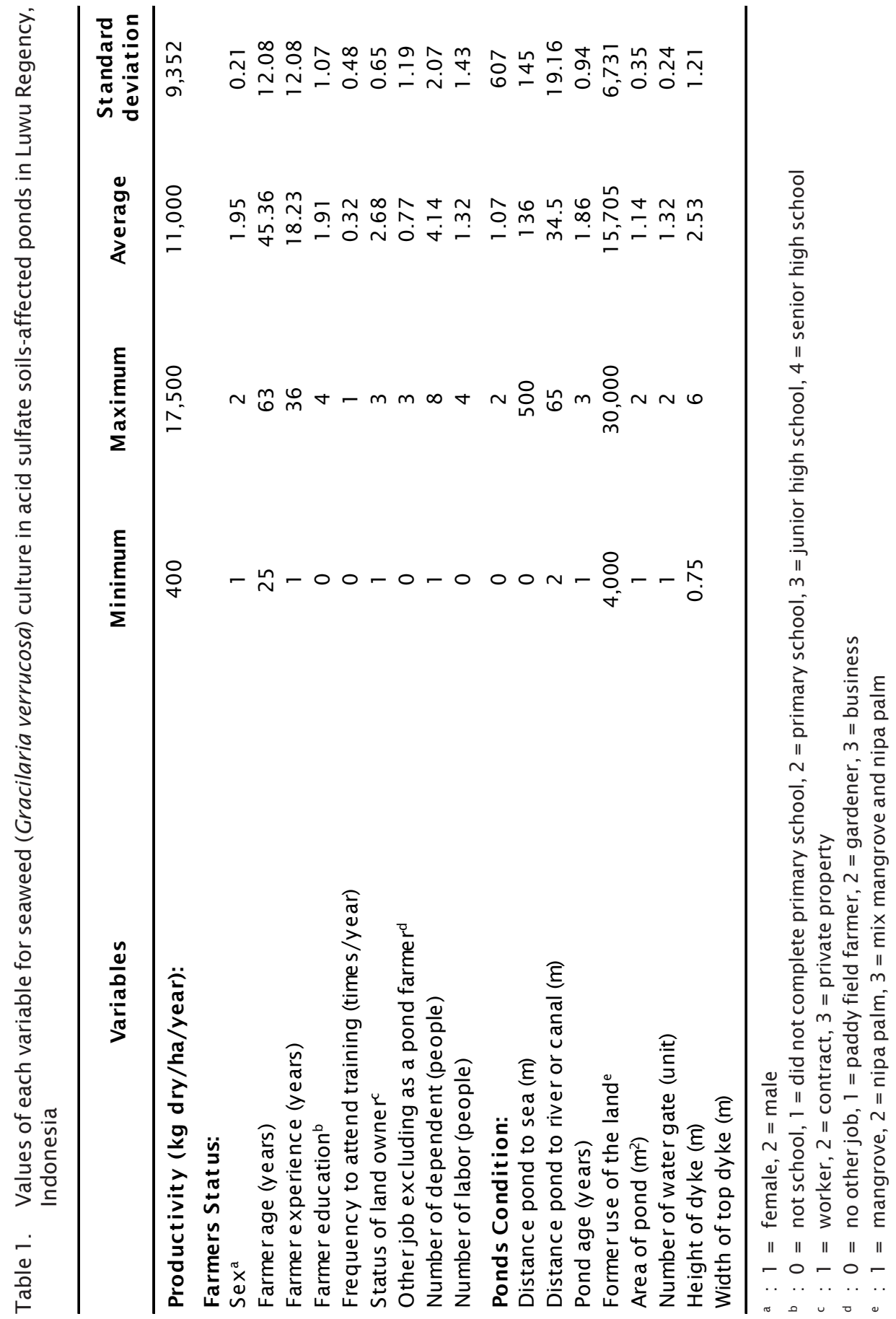




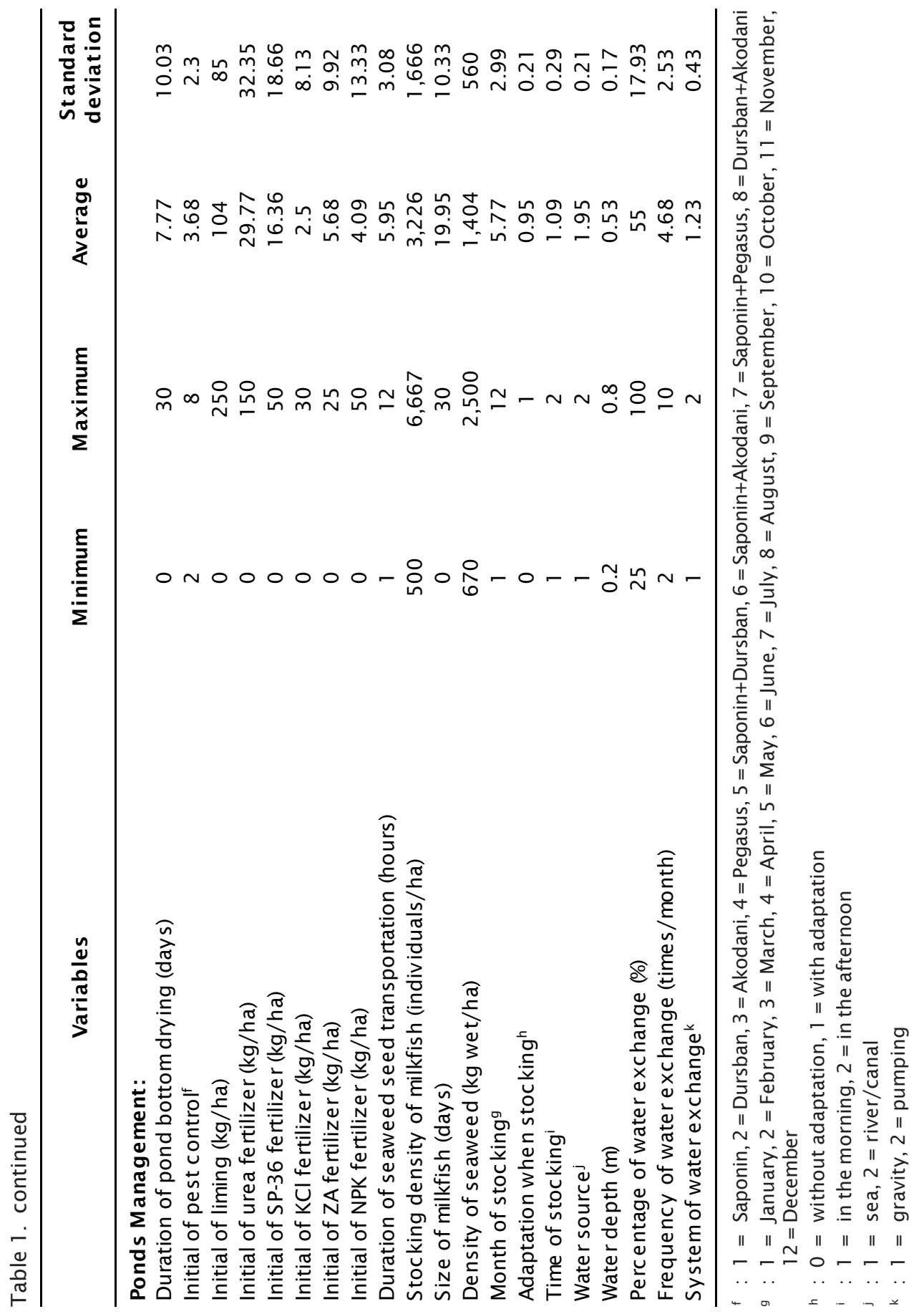




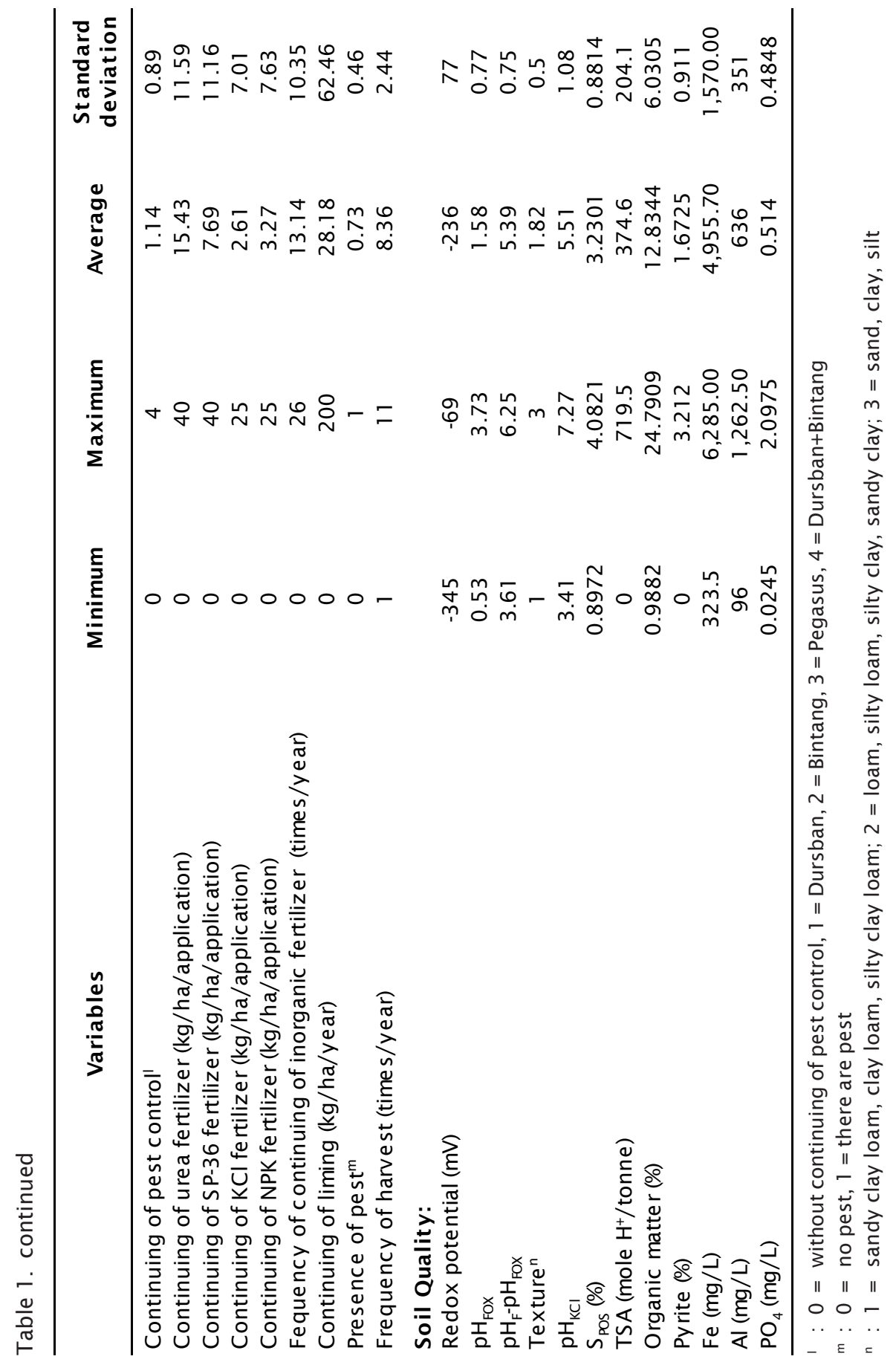




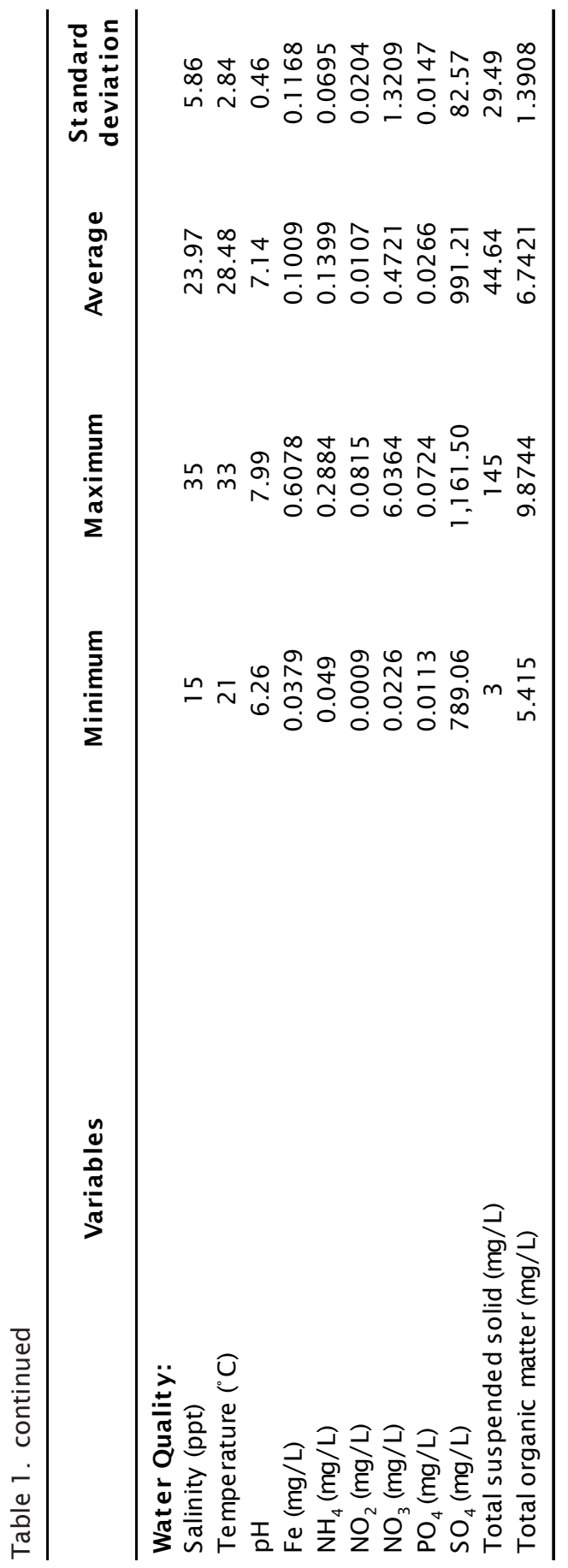


and mangrove areas some 35 years ago. The size of ponds in Luwu Regency ranges from 1 to 3 ha with 1.86 ha in average and almost all the ponds have only 1 unit water gate. All ponds for culturing seaweed are using the same canal as an outlet and inlet canal. In Bulukumba, Takalar and Maros Regencies, about $49.73 \%$ of the brackish water ponds size are less than 2.00 ha (Hanafi, 1990). The width of top dyke of the ponds varies between 0.75 and $6.00 \mathrm{~m}$. Pond with wider top dyke is used for drying seaweed.

Before seaweed and milkfish were stocked, some of the farmers conducted pond preparation including pond bottom drying, pest control, liming and fertilizing. The maximum of drying duration is 30 days, but there were farmers who did not conduct the pond bottom drying during the pond preparation. At least four different pesticides were being used by some of the farmers, i.e. Saponin, Dursban, Bintang, and Pegasus in the initial stage to control pest. But majority of the farmers were using Pegasus. About $67 \%$ of the farmers applied lime with very low dosage (104 kg/ha in average), although data showed the soil $\mathrm{pH}$ was acidic. Most of the farmers applied built lime, only two farmers applied dolomite. With regards to fertilizer application, all of the farmers were using inorganic fertilizer (urea, SP-36, KCl, ZA, NPK). Concentration of organic matter was high in the ASS-affected pond of Luwu Regency (12.8344\% in average).

All of the respondents were culturing seaweed (G. verrucosa) together with milkfish (Chanos chanos) in form of traditional polyculture system in ASS-affected pond of Luwu Regency. These two fisheries commodities can be cultured together in a brackish water pond because they have almost the same ecological requirements (Guanzon et al., 2004), but they occupy different ecological niche in brackish water pond. However, the main goal of the farmers is to produce the seaweed in this system and milkfish only for consuming. The density of seaweed stocked was 1,404 kg/ha and stocking density of milkfish was 3,226 individuals/ha. Most of the farmers stocked in the first week on June, because this month is the early of the dry season in the east coast of South Sulawesi, including Luwu Regency. When the dry season in Luwu Regency, the water quality especially salinity is relatively stable and high (20-35 ppt) in the ponds. Guanzon et al. (2004) said that production of milkfish and seaweed was higher during the dry season in Iloilo, Philippines. Bird \& MacLachlan (1986) stated that different species and strains of Gracilaria are generally euryhaline and their maximum growth occurrs at salinities of 15-38 ppt. Several cultivated Gracilaria sp. grow best at a salinity ranging from 18 to 30 ppt (Chen, 1976). According to Lin (1974), Gracilaria sp. grow fast in water of $25 \mathrm{ppt}$. The optimum salinity for Gracilaria sp. is $15 \mathrm{ppt}$, though they can survive in salinity from 5 to 50 ppt (Anonymous, 1991).

Water depth in the pond during the seaweed culture was $0.53 \mathrm{~m}$. This is the best condition for seaweed culturing in brackish water pond. Hendrajat \& Pantjara (2004) mentioned that the production of seaweed is better in the ASS-affected ponds with water depth of 0.50 $\mathrm{m}$ than that of $0.25,0.75$, and $1.00 \mathrm{~m}$. Recommended water depth of ponds for culturing seaweed is 0.5-0.8 m (Anonymous, 1991). The lower production of Gracilaria edulis obtained at low of water depth could be attributed to the adverse illumination and desiccation of fronds (Kaladharan et al., 1996). The authors also stated that at depth beyond $1.00 \mathrm{~m}$ the low production occurred due to the lack of sufficient quantum of light. Percentage of water exchange was $55 \%$ in average with ranges from $25 \%$ to $100 \%$ on each water exchange. The seaweed farmers conducted water exchange 5 times/month.

Continuing pest control was conducted to kill other fish, excluding milkfish. Most of the farmers were using Dursban or Bintang as a continuing pest control, because these pesticides can kill other fish in generally but not milkfish. The farmers also conducted continuing inorganic fertilizer, one week before and after harvest.

All farmers conducted the first harvest at 45 days after the seaweed were stocked and then every 20-30 days with harvest frequency of 8 times/year in average. A quarter to one third of the harvest was retained at every harvest and left in the ponds, which will continue to reproduce vegetatively for the next harvesting. Many researchers suggest for harvesting the first time at 45 days after stocked (Mubarak et al., 1990; Hurtado-Ponce et al., 1992; Kaladharan et al., 1996). Dry organic matter percentage in the fronds of Gracilaria sp. reached a maximum of $20.4 \%$ up to 45 days (Kaladharan et al., 1996). They also said that 
the daily growth rate of Gracilaria sp. decreased after the third harvest.

Low $\mathrm{pH}$ is a characteristic feature in ASS of Luwu Regency used for seaweed culture (Table 1). The low $\mathrm{pH}$ enhances solubility of trace elements, such as $\mathrm{Fe}, \mathrm{Al}$, and $\mathrm{Mn}$, the abundance of which becomes toxic to fish. In Luwu Regency, ASS were found with an average $\mathrm{pH}_{\mathrm{FOX}}$ of $1.58, \mathrm{pH}_{\mathrm{KCI}}$ of 5.51 , redox potential of $236 \mathrm{mV}, \mathrm{S}_{\mathrm{POS}}$ of $3.23 \%$, TSA of $374.6 \mathrm{~mol} \mathrm{H}^{+}$/ tonne, organic matter of $12.83 \%$, pyrite of $1.67 \%$, $\mathrm{Fe}$ of $4,956 \mathrm{mg} / \mathrm{L}, \mathrm{Al}$ of $636 \mathrm{mg} / \mathrm{L}$ and $\mathrm{PO}_{4}$ of $0.51 \mathrm{mg} / \mathrm{L}$. Such soil condition causes the pond production to be low, especially for shrimp unless improvement efforts are carried out. Soil texture in ASS-affected pond of Luwu Regency is dominated by loam, silty loam, silty clay and sandy clay.

Range of water temperature and $\mathrm{pH}$ were $21^{\circ} \mathrm{C}-33^{\circ} \mathrm{C}\left(28.48^{\circ} \mathrm{C}\right.$ in average $)$ and $6.26-7.99$ (7.14 in average). The optimum growth of $G$. verrucosa from Manila Bay, Philippines under controlled laboratory conditions was attained in temperature range of $25^{\circ} \mathrm{C}-30^{\circ} \mathrm{C}$ (HurtadoPonce \& Umezaki, 1987). The optimum temperature range for growth of milkfish is $20^{\circ} \mathrm{C}$ $43^{\circ} \mathrm{C}$ (Lin, 1969). Although, the ponds are constructed on ASS, the water $\mathrm{pH}$ is neutral. Most of the ponds are not dried or ponds in reduction condition that not produce the acidity. According to Bagarinao (1999), water pH ranging from 5 to 9 is most suitable for milkfish which cannot survive below $\mathrm{pH} 5$. However, according to Chen (1976), pH suited for Gracilaria sp farming should be between 6 and 9, with an optimum of 8.2-8.7. Gracilaria sp. will begin to deteriorate and finally disintegrate when the $\mathrm{pH}$ is below 6.5 (Liu, 1987).

Nitrogen in water plays a key role in aquaculture systems due to its dual function, as a nutrient and toxic. Average concentration of $\mathrm{NH}_{4}, \mathrm{NO}_{2}$, and $\mathrm{NO}_{3}$ in the water of brackish water ponds of Luwu Regency were 0.1399, 0.0107 and $0.4721 \mathrm{mg} / \mathrm{L}$, respectively. Gracilaria sp. uptake $\mathrm{NH}_{4}$ more rapid than $\mathrm{NO}_{3}$ (Ryther et al., 1981), however, Gracilaria sp. production was not affected by any nitrogen forms if the concentration is above the minimum in the water (Lapointe \& Ryther, 1978).

Based on the result of $F$ Test showed that from 75 variables that were analyzed only 21 variables of them have significant effect on the seaweed production or only 21 variables can be used to predict the seaweed produc- tion in ASS-affected ponds. Dominant variables to determine the seaweed production in the pond were also described in regression equation as follow:
$\mathrm{Y}=11,428+5 \mathrm{X}_{1}-1,427 \mathrm{X}_{2}+2,420 \mathrm{X}_{3}+1 \mathrm{X}_{4}-$ $18 X_{5}-145 X_{6}-8 X_{7}+102 X_{8}-2,239 X_{9}^{4}+$ $204 X_{10}+4,177 X_{11}-64 X_{12}-6 X_{13}+1,362 X_{14}$ $-31 X_{15}-86 X_{16}-433 X_{17}+105 X_{18}+2,992 X_{19}$ $+2,860 X_{20}-4 X_{21}$

(Equation 2)

where:

$Y=$ Seaweed production $(\mathrm{kg} / \mathrm{ha} /$ year $)$

$\mathrm{X}_{1}=$ Total organic matter of water $(\mathrm{mg} / \mathrm{L})$

$X_{2}=$ Number of dependents (people)

$\mathrm{X}_{3}=$ Frequency to attend the training (times)

$\mathrm{X}_{4}=$ Stocking density of milkfish (individuals/ ha/year)

$\mathrm{X}_{5}=$ Dosage of urea as a continuing fertilizer ( $\mathrm{kg} / \mathrm{ha} /$ year)

$\mathrm{X}_{6}=$ Dosage of $\mathrm{KCl}$ as an initial fertilizer $(\mathrm{kg} / \mathrm{ha})$

$\mathrm{X}_{7}=$ Concentration of Fe in the water $(\mathrm{mg} / \mathrm{L})$

$\mathrm{X}_{8}=$ Dosage of NPK as an initial fertilizer $(\mathrm{kg} /$ ha)

$\mathrm{X}_{9}=$ Presence of pest

$\mathrm{X}_{10}=\mathrm{pH}_{\mathrm{FOX}}$ of soil

$X_{11}=$ Number of water gate (unit)

$X_{12}=$ Percentage of water exchange (\%)

$\mathrm{X}_{13}=$ Dosage of urea as an initial fertilizer $(\mathrm{kg} /$ ha)

$\mathrm{X}_{14}=$ Other jobs excluding as a farmer

$\mathrm{X}_{15}=$ Total suspended solid of water $(\mathrm{mg} / \mathrm{L})$

$\mathrm{X}_{16}=\mathrm{NO}_{2}$ concentration of water $(\mathrm{mg} / \mathrm{L})$

$\mathrm{X}_{17}=$ Water temperature $\left({ }^{\circ} \mathrm{C}\right)$

$\mathrm{X}_{18}=$ Frequency of inorganic fertilizer (times)

$\mathrm{X}_{19}=$ Owner status of pond

$X_{20}=$ Number of labor (people)

$X_{21}=$ Distance of pond to source water $(m)$.

Average seaweed production in ASS-affected ponds of Luwu Regency was 11,000 $\mathrm{kg} / \mathrm{ha}$ /year (Table 1). It was higher than the seaweed production obtained from culture in ponds of Western Visayas, Philippines (3-4 t/ ha/year), but similar to the culture production in natural drainage canals (7-14 t/ha/year) (Hurtado-Ponce et al., 1992). Although, seaweed production in ASS-affected pond is high, there are yet the opportunities to increase the productivity to achieve minimum number of $11,428 \mathrm{~kg} / \mathrm{ha} /$ year.

Among variables of status farmer factor, there are 5 variables that have significant effect on the production of seaweed in ASSaffected ponds, i.e. number of dependent family, frequency to attend trainings, other jobs, 
owner status of pond and number of labor. From the Equation 2, it can be seen that the regression coefficient of dependent number is 1,427 . This indicates that the addition $1 \mathrm{mem}$ ber of dependent family will decrease (negative sign) $1,427 \mathrm{~kg} / \mathrm{ha} /$ year of seaweed production. On the contrary, addition of 1 time to attend the training and 1 people labor number will increase (positive sign) the production of seaweed 2,420 and $2,860 \mathrm{~kg} / \mathrm{ha} /$ year, respectively. If the farmers attend the training on aquaculture, the skill of farmers will increase and they can apply their knowledge on their ponds. Addition of labor number will increase the production of seaweed due to the increase the activity on the pond. More labor is required during pond preparation and harvesting in the brackish water ponds (Hanafi, 1990). Agricultural is a heavy activity that need power and time and the labor is needed for soil preparation and harvesting (Sugihen, 1996). Farmers that have another job will use their salary to buy necessities for brackish water pond such as fertilizer, lime and pesticide that can support for higher production.

Number of water gates and distance of pond to the water source are variables of pond condition factor that have significant effect on the production of seaweed in the ASS-affected ponds. Addition of water gates will increase the production of seaweed. Brackish water ponds that have two water gates means that water inlet and outlet are separated and better water quality for seaweed are expected. It is recommended that pond for seaweed culture should have a couple of drains (Anonymous, 1991). Brackish water ponds located closer to water source can yield higher productivity. Quantity and quality of water availability in the brackish water pond located closer to water source may be better for seaweed. Hanafi (1990) said that decreasing quality of water availability and drainage of brackish water pond will decrease fish production.

Elevating owner status of ponds of a farmer as a worker to contract and to privately owned will increase the productivity of ponds for seaweed. This relates to the productivity of pond managed by farmer as a worker and farmer works by contract. Sugihen (1996) said, in some Asian countries, sometimes the land owners lease their low productivity land to other farmers. The author also stated that, farmers as a worker culture the commodity for their necessity.
Among pond management factors, stocking density of milkfish, dosage of urea as continuing fertilizer, dosage of $\mathrm{KCl}$ as an initial fertilizer, the presence of pest, percentage of water exchange, dosage of urea as an initial fertilizer and frequency of inorganic fertilizer are variables that have significant effect on seaweed production. Average of stocking density of milkfish that was applied by the farmer was 3,226 individuals/ha/year. This value is the cumulative of milkfish stoked for a year, because some farmers stocked milkfish twice a year during the seaweed culture. Farmers are harvesting their milkfish after achieving 34 individuals $/ \mathrm{kg}$ to avoid the probability of the milkfish to eat the seaweed and then stock milkfish again. The presence of milkfish in the polyculture with seaweed can clean the seaweed from the klekap (a benthic complex of blue-green algae, protozoa, diatoms, bacteria, and detritus) and epiphyte. In the seaweed culture, farmers sometimes stocked milkfish with the aim to decrease the epiphyte in the pond, because the presence of epiphyte will decrease the seaweed quality (Retnowati et al., 1995; Sammut et al., 2003). Beside that, milkfish will create water motion and the mud that adhered in seaweed will be released. The next impact is diffusion process of nutrient into the seaweed will increase and the seaweed growth is better. The Equation 2 shows that regression coefficient of stocking density of milkfish was +1 . This indicates that the addition of 1 individuals of milkfish will increase the seaweed production up to $1 \mathrm{~kg}$.

The presence of pest, especially epiphyte such as Chaetomorpha sp in seaweed culture will likely decrease the seaweed production (regression coefficient of presence pest is 2,239; Equation 2). The epiphytes compete with the seaweed for light, nutrients, inorganic carbon and presumably also have an allelopathic effect (Friedlander \& Levy, 1995). It was already mentioned before that stocking density of milkfish applied by farmers was still low. This condition may cause the presence of epiphyte in the ponds. To decrease the number of Chaetomorpha sp. in the ponds is by increasing the number milkfish stocked in the ponds. Milkfish in Taiwan and Japan and sailfin molly (Poecilia latipinna) in the United State of America have recently shown to be promising epiphyte controllers in Gracilaria sp. culture, as they prefer eating the epiphytes rather the cultured Gracilaria sp. (Breden \& Bird, 1988; 
Anonymous, 1991). Friedlander et al. (1996) said that five species of fish consumed only epiphytes without damaging Gracilaria sp. in Israel, i.e. sailfin molly ( $P$. latipinna), guppy (Poecilia reticulate), zilli's cichlid (Tilapia zillii), killifish (Aphanius dispar), and pompano (Trachinotus ovatus).

Water exchange during the seaweed culture was $55 \%$ in average. Some farmers conducted water exchange up to $100 \%$ and leave seaweed in pond bottom without water for 3-4 hours, the water only in the surrounding canal of pond. Decreasing of percentage of water exchange will increase the seaweed production (Equation 2). During the seaweed was exposed to air, the seaweed might be dehydrated. Higher of percentage of water exchange can cause the seaweed need longer time to adapt to new water condition. Also, higher of percentage of water exchange can cause the fertilization not effective, because most of the fertilizer is flown out with the water.

The Equation 2 shows that increasing dosage of urea as initial fertilizer will decrease the seaweed production. This may be caused by the effect of the other fertilizers that contain of nitrogen such as ZA and NPK that were applied by farmers as an initial fertilizer. Also, increasing the dosage of urea as a continuing fertilizer can decrease seaweed production. Farmers in ASS-affected ponds applied urea $15.43 \mathrm{~kg} / \mathrm{ha} /$ application in average and some of the farmers applied urea a week before and after harvesting. This urea dosage for continuing fertilizer in the seaweed culture is high. Urea with dosage of $3 \mathrm{~kg} / \mathrm{ha}$ was added to fertilize the pond water of Gracilaria sp. culture (Anonymous, 1991). KCl fertilizer may be also needed too much for seaweed culture, because increasing the dosage of $\mathrm{KCl}$ fertilizer will decrease seaweed production. Potassium $(\mathrm{K})$ is available in pond water, because sea water containing $\mathrm{K}$ about $420 \mathrm{mg} / \mathrm{L}$ in $35 \mathrm{ppt}$ of salinity (Riley \& Chester, 1971). On the contrary, NPK fertilizer as an initial fertilizer will increase seaweed production about $102 \mathrm{~kg}$ dry/ha/year for every $1 \mathrm{~kg} \mathrm{NPK/ha.} \mathrm{Phosphate}$ is an important element for almost all organisms to support the transformation of metabolic energy (Kuhl, 1974). The concentration of phosphate in ASS is very low and its availability is also low because it bounds with iron and aluminum. Iron and aluminum are known to fix phosphate in high quantity (Singh, 1982).
From 17 soil variables that were analyzed, 12 of them were selected for multiple regression analysis. Only 1 soil variable has a significant effect on the seaweed production which was $\mathrm{pH}_{\text {Fox }}$. The $\mathrm{pH}_{\text {Fox }}$ is the soil $\mathrm{pH}$ after oxidation with $30 \%$ hydrogen peroxide. The increase of 1 unit of soil $\mathrm{pH}_{\mathrm{FOX}}$ until neutral condition will increase seaweed production up to 204 $\mathrm{kg}$ dry/ha/year in ASS-affected pond of Luwu Regency. Increasing pH of ASS can be done through remediation. Common remediation techniques for ASS in aquaculture involves drying to reduce oxidisable pyrite, flooding to dilute and neutralize acid to reduce further acid production, and flushing of leachate to minimize toxic reserves of acid in the soil (Mustafa, 2006). The other form of remediation is liming. Dosage of liming that was applied by farmers in ASS-affected ponds of Luwu Regency was s very low, only $28.18 \mathrm{~kg} / \mathrm{ha}$ /year in average (Table 1). The $S_{\text {pos }}$ measurement was used by Ahern et al. (1998a) to determine the lime requirement for ASS. For a bulk density of $0.89 \mathrm{~g} / \mathrm{cm}^{3}$ (Mustafa, 2006) and $\mathrm{S}_{\mathrm{POS}}$ from 0.8972 to $4.0821 \%$ in the surface layer, and if lime reacts to a depth of $0.05 \mathrm{~m}$, a pond in Luwu Regency will require approximately 18 to 83 tones of agricultural lime/ha (neutralizing value = 100 , safety factor $=1.5$ ). Because it needed lime in large number, it is suggested that remediation technique should be applied to increase the soil pH and decrease the concentration of toxic element.

Increasing dosage of urea as a continuing fertilizer will decrease the seaweed production. The increase of $\mathrm{NO}_{2}$ concentration in the water will decrease the seaweed production. Compare to the other forms of nitrogen $\left(\mathrm{NH}_{4}\right.$ and $\mathrm{NO}_{3}$ ), $\mathrm{NO}_{2}$ was used in small quantity b y seaweed farmers (Yang et al., 2006). Nitrite concentration in the water ponds was ranging from 0.0009 and $0.0815 \mathrm{mg} / \mathrm{L}$ (Table 1). Natural water contains $\mathrm{NO}_{2}$ about $0.001 \mathrm{mg} / \mathrm{L}$ (Council of Resource and Environment Ministers, 1987 in Effendi, 2003). Also, increasing the water temperature will decrease the seaweed production in ASS-affected ponds. The range water temperature in the pond was from $21^{\circ} \mathrm{C}$ to $33^{\circ} \mathrm{C}$. The optimum water temperature for seaweed is $25^{\circ} \mathrm{C}-30^{\circ} \mathrm{C}$. If the water temperature is more than $30^{\circ} \mathrm{C}$, the growth of seaweed will decrease. Water temperature that was more than $31^{\circ} \mathrm{C}$ was recorded in the pond with water depth less than $0.30 \mathrm{~m}$ in the midday. Increasing the total suspended solid of water 
also decreases the seaweed production. Higher concentration of water suspended solid will decrease the penetration of sunlight and cover the thallus of seaweed. Remediation of soil is also needed to decrease the concentration of Fe in the water. Iron is essential element for all organisms. In the plant, including algae, Fe functions as a cytochrom and chlorophyll builder (Effendi, 2003). However, higher Fe concentration can hinder the fixation of other elements. Iron concentration in the natural water is ranging from 0.05 and $0.20 \mathrm{mg} / \mathrm{L}$ (Boyd, 1995). Decreasing of concentration of Fe will increase the seaweed production in ASS-affected ponds.

\section{CONCLUSION}

The average of seaweed production in ASSaffected pond of Luwu Regency, Indonesia is high, about $11,000 \mathrm{~kg}$ dry/ha/year. In order to increase the production of seaweed, several efforts are recommended: (a) decreasing the dosage of urea and $\mathrm{KCl}$, and increasing the dosage and frequency of fertilizer containing phosphate, (b) increasing water depth in the pond and decreasing percentage of water exchange, (c) conducting remediation to increase the soil $\mathrm{pH}$ and decreasing the concentration of Fe in the water, (d) increasing stocking density of milkfish to decrease the epiphyte population and (e) increasing the frequency of the farmer to attend fish farming technical training.

\section{ACKNOWLEDGEMENTS}

This research was funded by the Australian Centre for International Agricultural Research (ACIAR) FIS/2002/076 (Land Capability Assessment and Classification for Sustainable Pond-based, Aquaculture Systems) in collaboration with the Research Institute for Coastal Aquaculture in Maros, Indonesia. The authors express thank to all members of ACIAR FIS/ 2002/076 for their assistance in the field and in the laboratory.

\section{REFERENCES}

Ahern, C.R. \& Blunden, B. 1998. Designing a soil sampling and analysis program. In: Ahern, C.R., Blunden, B. and Stone, Y. (eds.), Acid Sulfate Soils Laboratory Methods Guidelines. Acid Sulfate Soil Management Advisory Committee, Wollongbar, NSW., p. 2.1-2.6.
Ahern, C.R., Mc Elnea, A., \& Baker, D.E. 1998a. Acid neutralizing capacity methods. In: Ahern, C.R., Blunden, B. and Stone, Y. (eds.), Acid Sulfate Soils Laboratory Methods Guidelines. Acid Sulfate Soil Management Advisory Committee, Wollongbar, NSW., p. 6.1-6.4.

Ahern, C.R., McElnea, A., \& Baker, D.E. 1998b. Peroxide oxidation combined acidity and sulfate. In: Ahern, C.R., Blunden, B. and Stone, Y. (eds.), Acid Sulfate Soils Laboratory Methods Guidelines. Acid Sulfate Soil Management Advisory Committee, Wollongbar, NSW., p. 4.1-4.17.

Ahern, C.R., Mc Elnea, A., \& Baker, D.E. 1998c. Total oxidisable sulfur. In: Ahern, C.R., Blunden, B. and Stone, Y. (eds.), Acid Sulfate Soils Laboratory Methods Guidelines. Acid Sulfate Soil Management Advisory Committee, Wollongbar, NSW., p. 5.1-5.7.

Ahern, C.R. \& Rayment, G.E. 1998. Codes for acid sulfate soils analytical methods. In: Ahern, C.R., Blunden, B. and Stone, Y. (eds.), Acid Sulfate Soils Laboratory Methods Guidelines. Acid Sulfate Soil Management Advisory Committee, Wollongbar, NSW., p. 3.1-3.5.

Anonymous. 1991. Mariculture of seaweeds. In: Shokita, S., Kakazu, K., Tomori, A. and Toma, T. (eds.), Aquaculture in Tropical Areas. Midori Shobo Co., Ltd., Tokyo, p. 31-95.

Anonymous. 2003a. USA need seaweed of South Sulawesi. Fajar, Wednesday, 15 October 2003, p. 5.

Anonymous. 2003b. Seaweed of Luwu is the best in Indonesia. Fajar, Monday, 17 March 2003, p.16.

APHA (American Public Health Association). 2005. Standard Methods for Examination of Water and Wastewater. APHA-AWWA-WEF, Washington, D.C., 1,185 pp.

Bagarinao, T.U. 1999. Ecology and farming of milkfish. Philippine Journal of Science, 128(3): 193-211.

Bird, H.J. \& MacLachlan, J. 1986. The effect of salinity on distribution of species of Gracilaria Grev. (Rhodophyta: Gigartinales): an experimental assessment. Botanica Marina, 29: 231-328.

Boyd, C.E. 1995. Bottom Soils, Sediment, and Pond Aquaculture. Chapman and Hall, New York, $348 \mathrm{pp}$.

Breden, C. \& Bird, K.T. 1988. Use of Poecilia latipinna (sailfin molly) for control of nui- 
sance algae in Gracilaria verrucosa strain G-16 (seaweed) culture. Journal of the World Aquaculture Society, 19: 161-162.

Capo, Th.R., Jaramillo, J.C., Boyd, A.E., Lapointe, B.E., \& Seraty, J.E. 1999. Sustained high yields of Gracilaria (Rhodophyta) grown in intensive large-scale culture. Journal of Applied Phycology, 11:143-147.

Chen, T.P. 1976. Culture of Gracilaria. In: Aquaculture Practices in Taiwan. Page Bros, London, p. 145-149.

Daud, R., Yakob, M.J.R., \& Suwardi. 1994. Quality of seaweed, Gracilaria sp. in the different of soil quality of ponds. RICA News, 6(2): 810.

Daugherty, B.K. \& Bird, K.T. 1988. Salinity and temperature effects on agar production from Gracilaria verrucosa Strain G-16. Aquaculture, 75: 105-113.

Draper, N.R. \& Smith, H. 1992. Applied Regression Analysis. Second Edition. John Wiley \& Sons, New York, 709 pp.

Effendi, H. 2003. Analysis of Water Quality for Resources Management and Water Environment. Penerbit Kanisius, Yogyakarta, 258 $\mathrm{pp}$.

Freile-Pelegrin, Y. \& Murano, E. 2005. Agars from three species of Gracilaria (Rhodophyta) from Yucatán Peninsula. Bioresource Technology, 96: 295-302.

Friedlander, M. \& Levy, I. 1995. Cultivation of Gracilaria in outdoors tanks and ponds. Journal of Applied Phycology, 7: 31 5-327.

Friedlander, M., Shalev, R., Ganor, T., Strimling, S, Ben-Amotz, A., Klar, H., \& Wax, Y. 1987. Seasonal fluctuations of growth rate and chemical composition of Gracilaria cf. conferta in outdoor cultivate in Israel. Hydrobiologia, 151/152: 501-507.

Friedlander, M., Weintraub, N., Freedman, A., Sheer, J., Snovsky, Z, Shapiro, J., \& Kissil, G.Wm. 1996. Fish as potential biocontrollers of Gracilaria (Rhodophyta) culture. Aquaculture, 145: 113-118.

Guanzon, N.G.Jr., de Castro-Mallare, T.R., \& Lorgue, F.M. 2004. Polyculture of milkfish Chanos chanos (Forsskal) and the red seaweed Gracilariopsis bailinae (Zhang et Xia) in brackish water earthen ponds. Aquaculture Research, 35: 423-431.

Guerin, J.M. \& Bird, K.T. 1987. Effects of aeration period on the productivity and agar quality of Gracilaria sp. Aquaculture, 64: 105-110.
Hanafi, A. 1990. Socio-economic and managerial profiles of brackishwater aquaculture in South Sulawesi. Journal of Coastal Aquaculture, 6(2): 97-114.

Hendrajat, E.A. \& Pantjara, B. 2004. Effects of water depth on the growth of seaweed, Gracilaria verrucosa in the acid sulfate soil affected-ponds. In: Bengen, D.G., Sidik, A.S., Helminuddin, Muslim, A.B., Zain, B., Saleh, M.K., Noryadi, Suyatna, I., Zainuri, M., Abdunnur and Makinuddin, N. (eds.). Proceeding of IV National Conference on Resources Management of Open Waters, Coastal, Small Islands and Ocean of Indonesia. Konas Kaltim, Balikpapan, p. II.276II.282.

Hurtado-Ponce, A.Q., Samonte, G.Pb., Luhan, Ma.R., \& Guazon, N.Jr. 1992. Gracilaria (Rhodophyta) farming in Panay, Western Visayas, Philippines. Aquaculture, 105: 233240.

Hurtado-Ponce, A.Q. \& Umezaki, I. 1987. Growth rate studies of Gracilaria verrucosa (Gigartinales, Rhodophyta). Botanica Marina, 30:223-226.

Kaladharan, P., Vijayakumaran, K., \& Chennubhotla, V.S.K. 1996. Optimization of certain physical parameters the mariculture of Gracilaria edulis (Gmelin) Silva in Minicoy lagoon (Laccadive Archipelago). Aquaculture, 139: 165-270.

Klepper, O., Hatta, Gt.M., \& Chairuddin, Gt. 1990. Environmental impacts of the reclamation of potential acid sulphate soils in Indonesia. Indonesian Agricultural Research \& Development Journal, 12(2): 29-34.

Kuhl, A. 1974. Phosphorus. In: W.D.P. Stewart (ed.). Algal Physiology and Biochemistry. Botanical Monographs. Volume 10. Blackwell Scientific Publication, Oxford, London, Edinburgh, Melbourne, p. 636-654.

Lapointe, B.E. \& Ryther, J.H. 1978. Some aspects of the growth and yield of Gracilaria tikvahiae in culture. Aquaculture, 15: 185193.

Lin, H.S. 1969. Some aspects of milkfish ecology. Chinese-American Joint Commission for Rural Reconstruction. Fisheries Series, 17: 68-90.

Lin, M.N. 1974. Culture of Gracilaria. Fish Research Institute, Keelung, p. 1-8.

Liu, S. 1987. Study on the commercial cultivation of Gracilaria in South China. Chinese Journal of Oceanology and Lymnology, 5: 281-283. 
Marinho-Soriano, E. \& Bourret, E. 2003. Effects of season on the yield and quality of agar from Gracilaria species (Gracilariaceae, Rhodophyta). Bioresource Technology, 90: 329-333.

Melville, M.D. 1993. Soil Laboratory Manual. School of Geography, The University of New South Wales, Sydney, 74 pp.

Menon, R.G. 1973. Soil and Water Analysis: A Laboratory Manual for the Analysis of Soil and Water. Proyek Survey O.K.T. Sumatera Selatan, Palembang, $191 \mathrm{pp}$.

Mubarak, H., Ilyas, S., Ismail, W., Wahyuni, I.S., Hartati, S.T., Pratiwi, E., Jangkaru, Z., \& Arifudin, R. 1990. Technical Guideline for Seaweed Culture. Centre Research and Development of Fisheries, Jakarta, 93 pp.

Mustafa, A. 2006. Improving Acid Sulfate Soils for Brackish Water Aquaculture Ponds in South Sulawesi Indonesia. Doctor of Philosophy Thesis. The University of New South Wales, Sydney, $418 \mathrm{pp}$.

Mustafa, A. \& Ratnawati, E. 2005. Effect of management factors on seaweed (Gracilaria verrucosa) in acid sulfate soils-affected ponds (case study in Luwu Regency, South Sulawesi Province). Indonesian Fisheries Research Journal, 11 (7): 67-76.

Padda, H. 1986. Brackish water ponds farming in Jeneponto Regency, South Sulawesi. Journal of Coastal Aquaculture, 2(1 \& 2): 1 74183.

Peñaflorida, V.D. \& Golez, N.V. 1996. Use of seaweed meals from Kappaphycus alvarezii and Gracilaria heteroclada as binders in diets for juvenile shrimp Penaeus monodon. Aquaculture, 143: 393-401.

Rasjid, F., Kahar, Tompo, A., Utojo, \& Ismail, A. 1993. Effects of stocking density in polyculture among seaweed, tiger prawn and milkfish on the ponds productivity. In: Hanafi, A., M. Atmomarsono and S. Ismawati (eds.). Proceeding of Seminar on Research Results of Coastal Aquaculture. Research Institute for Coastal Aquaculture, Maros, p. 73-78.

Retnowati, N., Murtini, J.T., Wibowo, S., \& Suparno. 1995. Marketing study to support seaweed culture. In: Cholik, F., Rukyani, A., Sarnita, A.S., Heruwati, E.S., Suparno, Monintja, D., Soewardi, K., Widodo, J. and Nikijuluw, V.P. (eds.), Proceeding of I Indonesian Fisheries Symposium, Book II Aspect: Postharvest, Socio Economic and
Capture. Centre Research and Development of Fisheries, Jakarta, p. 289-302.

Riley, J.P. \& Chester, R. 1971. Introduction to Marine Chemistry. Academic Press, London, $465 \mathrm{pp}$.

Ryther, J.H., Corwin, N., DeBusk, T.A., \& Williams, L.D. 1981. Nitrogen uptake and storage by the red alga Gracilaria tikvahiae (Mc Lachlan, 1979). Aquaculture, 26: 107-1 15.

Sammut, J. \& Lines-Kelly, R. 2000. An Introduction to Acid Sulfate Soils. Natural Heritage Trust, Australia, $27 \mathrm{pp}$.

Sammut, J., Mustafa, A., Hanafi, A., Tarunamulia, M., \& Tahe, S. 2003. Polyculture: extends production life for ponds with acid sulfate soil. Global Aquaculture Advocate June, Volume 6, Issue, 3: 72-73.

Santelices, B. \& Doty, M.S. 1989. A review of Gracilaria farming. Aquaculture, 78: 95-133.

Sfriso, A., Marcomini, A., \& Pavoni, B. 1994. Gracilaria distribution, production and composition in the Lagoon of Venice. Bioresource Technology, 50: 165-173.

Singh, V.P. 1982. Kinetic of acidification during inundation of previously dried acid sulfate soil material: implication for the management of brackish water fishponds. In: Dost, H. and van Breemen, N. (eds.), Proceedings of the Bangkok Symposium on Acid Sulphate Soils. ILRI Publication 31. International Institute of Land Reclamation and Improvement, Wageningen, p. 331353.

Sugihen, B.T. 1996. Rural Sociology (An Introduction). PT RajaGrafindo Persada, Jakarta, $183 \mathrm{pp}$.

Sukadi, M.F. 2006. Development of seaweed culture in Indonesia. In: Cholik, F., Moeslim, S., Heruwati, E.S., Ahmad, T. and Jauzi, A. (eds.), 60 years of Indonesian Fisheries. Masyarakat Perikanan Nusantara, Jakarta, p. 213-223.

Troell, M., Halling, C., Nilsson, A., Buschmann, A.H., \& Nauttsky, N. 1997. Integrated marine cultivation of Gracilaria chilensis (Gracilariales, Rhodophyta) and salmon cages for reduced environmental impact and increased economic output. Aquaculture, 156: 45-61.

Valente, L.M.P., Gouveia, A., Rema, P., Matos, J., Gomes, E.F., \& Pinto, I.S. 2006. Evaluation of three seaweeds Gracilaria bursapastoris, Ulva rigida and Gracilaria cornea as dietary ingredients in European sea bass 
(Dicentrachus labrax) juveniles. Aquaculture, 252: 85-91.

Wang, G.C. 2002. Isolation and purification of phycoerythrin from red alga Gracilaria verrucosa by combined expanded bed adsorption and ion exchange chromatography. Chromatographia, 56: 509-513.

Westermeier, R., Gómez, I., \& Rivera, P. 1993. Suspended farming of Gracilaria chilensis
(Rhodophyta, Gigartinales) at Cariquilda River, Maullín, Chile. Aquaculture, 113:215229.

Yang, Y.F., Fei, X.G., Song, J.M., Hu, H.Y., Wang, G.C., \& Chung, I.K. 2006. Growth of Gracilaria lemaneiformis under different cultivation conditions and its effect on nutrient removal in Chinese coastal waters. Aquaculture, 254: 240-255. 